smelter until the power supply for it is settled, so there could be a long delay. British Aluminium, it is thought, will settle for the site at Invergordon, using electricity from the North of Scotland Hydro-electric Board. Negotiations for the contract, to last until the end of the century, are likely to be protracted, but the hydro board claims that this will not delay the commissioning of the smelter beyond 1971, the same year as Alcan.

In all this, one point has been almost entirely overlooked. Instead of an output of 240,000 tons from two smelters, the Government has now provided for an annual production of 320,000 tons, from three smelters. This side-stepped the problem of having to choose between the different companies, but has inevitably increased the concern felt by other producers of aluminium, principally those in Norway. Norway claims, not unreasonably, that the establishment of smelters in Britain involves subsidies which contravene the EFTA convention. It is bound to feel that the terms offered by the Coal Board include an element of subsidization. The Coal Board denies this, but the impression remains that Norway, and the users of coal in Britain, have been shabbily treated.

\section{What Next for ESRO?}

THE European Space Research Organization (ESRO) has at last had its first major success-the launching last month of the satellite ESRO 2 (rechristened IRIS now it is in orbit)-and has at the same time published its general report for 1967 which is a sad chronicle of all that befell it last year. Only because the report was obviously written some time before the cancellation of the TD 1 and TD 2 satellites and the crisis in ELDO, does it escape unmitigated gloom. Even so, it is clear that uncertainty about the future is ESRO's principal worry at the moment, and the organization is waiting anxiously for the meeting of the European Space Conference to be held in Bonn some time in the autumn, when it hopes that suspense will be lifted. The European Space Conference is a meeting of ministers concerned with space affairs from the various ESRO countries which last met almost a year ago, when it decided that ESRO should start no new projects for the time being at least.

That ban was imposed to give ESRO time to reorganize itself along the lines of the Bannier report, which recommended a greater delegation of authority and criticized ESRO for being too inflexible and complex for a scientific organization. This lesson has clearly been taken to heart. Last year saw the setting up of a new management structure. Replacing the clear separation between the scientific directorate and the technical directorate which was previously a feature of the organization's structure, the distinction is now between the part of the organization responsible for defining long-term policy and the part concerned with its implementation.

Clearly ESRO believes that the standstill imposed by the European Space Conference does not extend to thinking about new projects. Apart from detailed studies on the Large Astronomical Satellite project (LAS) and on communications satellites, it carried out a dozen feasibility studies for scientific satellites including further versions of the HEOS satellites, a solar satellite, a geostationary satellite, and a satellite with an adjustable orbit. It is also clear from the report that ESRO is concerned about its relationship with ELDO, the European Launcher Development Organization. For one thing, it is going to be more expensive to launch satellites with rockets developed by ELDO than by using the corresponding United States launchers. Another problem arguing against European launchers is that they will be larger than ESRO requires, at least in the foreseeable future. Although at first sight this seems to put ESRO in an enviable position as far as availability of launchers is concerned, the organization can hardly take advantage of this. Large launchers could only be fully utilized by combining some tens of small experiments in one satellite. Fitting together a large number of experiments in one satellite, making them compatible and incorporating all the necessary probes, solar cell panels and aerials is no mean task, as the Orbiting Geophysical Observatories developed in the United States have shown. The policy of the organization as far as launching rockets is concerned must again wait on the decisions of the European Space Conference.

It is no secret that the Italians are concerned about the way ESRO contracts are handled, and the general report admits that the policy of free tendering for contracts is not going to even out the differences in the technical capabilities of the member states. For example, up to the end of 1967 the value of contracts awarded to French industry was 38 per cent of all ESRO contracts, compared with the French contribution of 20 per cent to the ESRO budget. Italy, on the other hand, paying 11 per cent of ESRO's budget, received 7.5 per cent of the contracts. Britain receives 17 per cent of the contracts for its contribution of 24 per cent. Aware of this disparity, the organization feels it should encourage the member states to concentrate on particular aspects of space technology. Until this is achieved, ESRO seems to hope to stave off criticism by seeing that the percentage share of the contracts awarded to each member state is at least 70 per cent of its percentage contribution to the budget.

What is clear from the report is that the European Space Conference should not delay its decision on the future of European space co-operation much longer. European space contractors, and ESRO itself, need to know what kind of projects are likely to form the basis of the organization's work in the future. The meeting in Bonn in the autumn is likely to see an end to the more ambitious projects which ESRO has been tinkering with in the past, and a return to a more realistic view of what European technical co-operation is capable of at present. The sounding rocket programme, and the setting up of the range at Kiruna, invaluable for high altitude work, are examples of the kind of project ESRO can successfully undertake. An organization working at this level, together with a few launchings of small satellites, should provide a toe-hold for European space ambitions, and ensure that the facilities built up by ESRO are not wasted.

\section{Jodrell Bank in Wales}

Trre design studies for the Mark $\mathrm{V}$ radio telescope for Jodrell Bank are now well advanced and should be finished by the end of the year. With an assurance from the Science Research Council that the scheme will be given a measure of priority, the University of Man- 